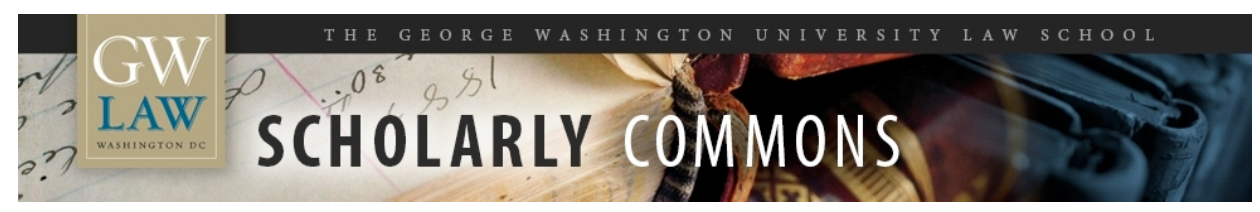

\title{
Constitutional Obstacles to Regulating Violence in the Media
}

Catherine J. Ross

George Washington University Law School, cross@law.gwu.edu

Follow this and additional works at: https://scholarship.law.gwu.edu/faculty_publications

Part of the Law Commons

\section{Recommended Citation}

Catherine J. Ross, Constitutional Obstacles to Regulating Violence in the Media, in HANDBOOK OF CHILDREN, CULTURE, AND VIOLENCE 291 (Nancy E. Dowd et al. eds., 2006).

This Chapter is brought to you for free and open access by the Faculty Scholarship at Scholarly Commons. It has been accepted for inclusion in GW Law Faculty Publications \& Other Works by an authorized administrator of Scholarly Commons. For more information, please contact spagel@law.gwu.edu. 


\section{HANDBOOKOF}
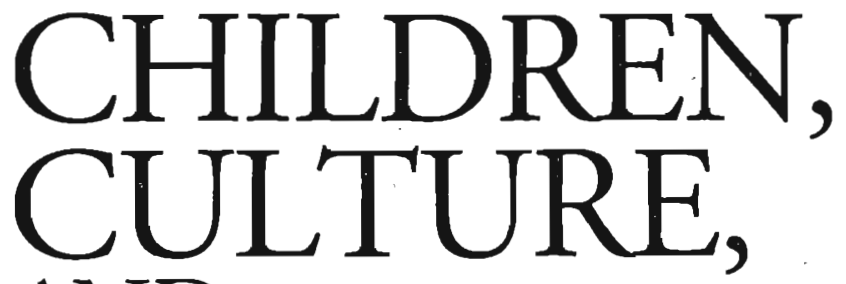

AND

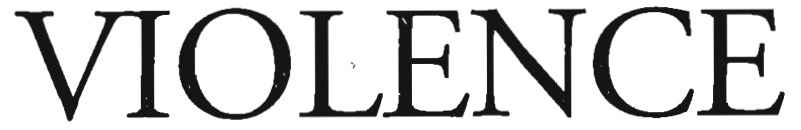

EDIED BY

Nancy E. Dowd

University of Florida, Levin College of Law

Dorothy G. Singer

Yale University

Robin Fretwell Wilson

University of Maryland, School of Law 


\title{
Constitutional Obstacles to Regulating Violence in the Media
}

\author{
Catherine J. Ross
}

A

$t$ the start of the 21st century, roughly $80 \%$ of Americans believe that too much violence is displayed in the media (Bok, 1997). Many parents, social scientists, and educators wish that the government would intervene to protect children from violent images. They worry that graphic media violence has a "deleterious influence on the young" and contributes to violence in the real world. Parents have long been warned to protect their children from violence found in cheap novels and popular music, in comics, movies and television, and, most recently, in computer materials and video games (Broadcast Decency Enforcement Act, 2004; Ross, 1997, 2000).

When harm to children is invoked, the average citizen, legislator, and even judge is too often tempted to disregard the strictures of the Constitution which pose formidable obstacles to any government effort to restrict violent speech (Ross, 2000, as cited in ACLU v. Reno, 2000, p. 181). The Speech Clause of the First Amendment provides in pertinent part, "Congress shall make no law ... abridging the freedom of speech, or the press" (U.S. Const., Amend. 1). This chapter separates speech containing violent imagery from other forms of speech that become controversial when made available to children, and considers whether such "violent speech" can be subjected to government regulation that will survive constitutional scrutiny.

The first section of this chapter briefly reviews the limits the Speech Clause places on the government's power to regulate speech. The second section demonstrates that violent speech may not be regulated based on its content (i.e., "violence") because it does not fit the limited legal categories constituting "unprotected" speech, such as obscenity. The third section examines the government's burden to demonstrate that violent speech harms children before it can regulate such speech, and concludes that current social science evidence does not meet the constitutional standard. The fourth section discusses the inherent difficulties in defining violent speech in a way that satisfies the demands of the First Amendment. The fifth section argues that private efforts by parents and industry provide the best, and probably the only constitutional, response to the problem of media violence. 


\section{AN INTRODUCTION TO FREEDOM OF SPEECH}

The Speech Clause occupies a privileged place among the guarantees of the Bill of Rights. It is the key to an open marketplace of ideas that, in turn, is critical to a functioning democracy. The marketplace of ideas, through which "good" speech will presumably overcome "bad" speech, is a prerequisite for an informed citizenry that is seen as essential to democracy (Dienes, Levine, \& Lind, 1999).

Freedom of speech, like other civil liberties, is not absolute. It may, for example, be subject to "reasonable time, place, and manner regulations," (Police Dep't of the City of Chicago v. Mosley, 1972, p. 98), but never on the basis of its content or viewpoint. As the Supreme Court has explained, "above all else, the First Amendment means that government has no power to restrict expression because of its message, its ideas, its subject matter or its content" (Mosley, p. 95). Because the Speech Clause is designed to prevent any suppression of speech that is motivated by the state's disapproval of the ideas expressed, the essence of censorship, "[c]ontent-based regulations are presumptively invalid" (R.A.V. v. City of St. Paul, 1992, p. 382). The Supreme Court has emphasized that, "if there is a bedrock principle underlying the First Amendment it is that the government may not prohibit the expression of an idea simply because society finds the idea itself offensive or disagreeable" (Texas v. Jobnson, 1989, p. 414). The source of the government's regulation-legislative or regulatory, at the federal, state, or local level-is irrelevant to the analysis. All are governed by the First Amendment.

Any government effort to restrict speech containing violence or violent imagery would, on its face, be aimed at the content of the speech, and therefore would be presumptively invalid. "Violent speech" defies clear definition, as discussed in Part IV below. It includes pictures and conduct as well as words about violence or depicting violence. The lack of agreement about what sorts of violence to worry about has led to dissatisfaction with industry ratings systems. For example, when one mother screened a familyrated film, Fiddler on the Roof, her son ran screaming from the room as the Cossacks tormented the Jews, yelling "what kind of parents would show a scary movie like this to a little kid?" (Salamon, 2005). The same 8year-old had happily watched films rated "parents strongly cautioned" and "not appropriate for those under age 17" such as The Matrix and the Lord of the Rings, both of which clearly involved fantasy worlds rather than history.

When a government regulation affecting speech is challenged in court, the regulation is subjected to "strict scrutiny," as opposed to the deferential "rational basis" or mere "legitimacy" standard governing most reviews of government actions. Under strict scrutiny, a regulation based on the content of speech (such as any regulation of "violent speech") will be found unconstitutional unless the government can demonstrate: (i) a compelling government interest that justifies regulation and (ii) that the regulation is "narrowly tailored" to achieve the state's goal without limiting more speech than is absolutely necessary (Sable Communications, Inc. v. FCC, 1989). The impact of these principles on potential government regulations designed to limit the exposure of minors to violent speech is considered in the following sections.

\section{IS VIOLENT SPEECH CONSTITUTIONALLY PROTECTED SPEECH?}

The easiest way to justify regulation of violence in any form of media, and avoid the rigors of strict scrutiny, would be to argue 
that it is not "speech" protected by the First Amendment. If "violent speech" were shown not to be "speech" within the protection of the First Amendment, government regulation would only be subject to deferential "rational basis" review. Efforts to claim that violent speech is not protected speech are, however, unlikely to succeed.

Most scholars agree that the Supreme Court has already rejected the notion that violent speech is unprotected speech. More than a half century ago, the Supreme Court overturned a New York City statute criminalizing the publication and distribution of "publications devoted principally to criminal news and stories of bloodshed, lust or crime" (Winters v. New York, 1948, p. 667). The Court rejected the notion that the Speech Clause only covered "the exposition of ideas" (p. 667). The Court explained that line-drawing between "ideas" and other forms of communication was impossible:

The line between informing and entertaining is too elusive for the protection of that basic right. Everyone is familiar with instances of propaganda through fiction. What is one man's amusement, teaches another's doctrine. Though we can see nothing of any possible value in these [crime] magazines, they are as much entitled to the protection of free speech as the best of literature. (p. 667)

Some lower federal courts initially viewed video games as simply not speech. In the 1980s, a handful of federal lower courts accepted the argument that violence in one particular form of media-video games-did not comprise speech (Phillips, 2004). Judges held that games like "Pacman" lacked content, were not communicative, and therefore were not speech (American Best Family Showplace Corp. v. City of New York, 1982). Since that time, however, federal appellate courts have found that modern, sophisticated video games have story lines, and therefore are communicative and fall within the legal definition of speech (American Amusement Machine Ass'n $v$. Kendrick, 2000; Interactive Digital Software Ass'n v. St. Louis County, 2003). The rare lower court judge who has denied First Amendment protection to video games on any grounds has been reversed in the appellate courts (American Amusement Machine Ass'n v. Kendrick, 2000; Interactive Digital Software Ass'n v. St. Louis Country, 2002). Violence in every other form of media-from print to music, cable television, and movieshas uniformly been treated as speech protected by the First Amendment. Thus, any regulation of such speech based on its violent content would be subject to strict scrutiny regardless of the form in which it appears.

One might argue that violent speech could be subsumed into categories that the Supreme Court views as "unprotected" speech. The Court has carved out narrow categories of speech that are subject to government regulation because they are "of such slight social value that any benefit that may be derived from them is clearly outweighed by the social interest in order and morality" (Chaplinsky v. New Hampshire, 1942, p. 572). The categories of such "low-value" speech are (i) defamation (New York Times v. Sullivan, 1964); (ii) "fighting words" (Chaplinsky v. New Hampshire, 1942) and incitement (Brandenberg $v$. Obio, 1969); and (iii) obscenity (Miller v. California, 1973). If one of those categories could be stretched to encompass violent speech, the government could regulate the imagery. The government, however, would have to regulate the entire category. The government may proscribe an entire category of so-called low-value speech based on its content, but may not pick and choose within the category based on the speaker's viewpoint. For example, libel of gov ernment officials could not be banned while allowing other forms of libel.

Under this analysis, the threshold question is whether speech containing violent content 
fits within the rubric of one of the narrow categories of speech subject to content-based regulation.

\section{DEFAMATION}

The treatment of defamation as unprotected speech adapts the common law of libel to a constitutional standard. The common law provided an individual with the opportunity to sue a speaker for damages when the speaker had made or published false statements that damaged the individual's reputation. At the risk of oversimplification, the constitutional adaptations made by the Supreme Court protect vigorous debate about public figures (Kalven, 1989), while otherwise permitting a cause of action for defamation to proceed. Defamation clearly does not overlap with violence, even if it involves a false accusation that an individual acted in a violent manner.

\section{Fighting Words and Incitement}

The concept of "fighting words" at first glance appears to offer a much more likely possibility that it might incorporate some forms of violent speech. But "fighting words" that may be constitutionally subject to criminal penalties has an extremely narrow scope. It applies only when the speaker says something that would provoke most people to fight (Chaplinsky v. New Hampshire, 1942; Kalven, 1989). The government's interest in such cases is to prevent immediate physical and social disorder. Violent speech contained in various forms of media entertainment cannot be squeezed into the rubric of "fighting words" because the imagery is normally too far removed from any action to which it might arguably contribute.

"Incitement to violence" is also very narrow. It requires specific incitement to engage in "imminent unlawful activity" (Brandenburg v. Obio, 1969). Under this doctrine, the speaker must intend to incite listeners to immediate action (Hess $v$. Indiana, 1973; Li, 2003). Finding promise in this approach, some individuals have brought tort actions against the producers of violent movies, video games, and rock music. Each of the cases was brought by parents whose children had died, either as suicides or as the victims of what the plaintiffs considered to be imitation of violence portrayed in various forms of entertainment. These crimes included several notorious school shootings, allegedly inspired by films or video games. None of these suits has succeeded. Indeed, according to Montz (2002), no claim survived the earliest stages of a lawsuit, defendants' motions for dismissal or summary judgment, at either the trial court or appellate level. Courts have rejected these tort claims on their face after applying tort law or the doctrine of "imminent unlawful activity" enunciated in Brandenberg. Among other things, courts have held that such violence is not reasonably foreseeable, and that, absent any intent to incite violence, the producers owe no duty to the victims under tort law. More important for this discussion, the speech at issue is protected by the First Amendment unless it satisfies the high demands of the incitement exception, including intent and immediacy.

\section{Obscenity}

Another category of unprotected speech that might seem to subsume some forms of violent speech is "obscenity." The Supreme Court has struggled since it first considered the problem of obscenity in 1957 to define and apply a standard distinguishing hardcore "obscene" speech, which is outside the protection of the First Amendment, from merely indecent speech, which is protected from government regulation (Miller $v$. California, 1973; Roth v. United States, 1957). The confusion over what constitutes 
obscenity is so great that one member of the Court metaphorically threw up his hands, saying "I know it when I see it" (Jacobellis $\nu$. Obio, 1964, p. 197).

The current test for obscenity, crafted by the Supreme Court in Miller v. California (1973) has three parts, each of which must be satisfied before a work is deemed obscene:

(a) whether "the average person, applying contemporary community standards," would find that the work, taken as a whole, appeals to the prurient interest;

(b) whether the work depicts or describes, in a patently offensive way, sexual conduct specifically defined by the applicable state law; and

(c) whether the work, taken as a whole, lacks serious literary, artistic, political, or scientific value (p. 24).

Perhaps the most difficult problem in applying Miller $v$. California is who defines which works have "serious literary, artistic, political or scientific value." This phrase and other variables have made the test for legal obscenity difficult to administer. The Court's efforts to define obscenity in order to distinguish protected from unprotected speech have generated much criticism (Paris Adult Theatre I v. Slaton, 1973).

It is important to appreciate the constitutional protection accorded even to highly sexualized speech that does not meet the test for obscenity. As the Supreme Court stated in United States $v$. Playboy Entertainment Group, Inc. (2000), "we shall assume that many adults themselves would find the material highly offensive" (p. 811). But if it is not obscene, "adults have a constitutional right to view it” (p. 812). It has long been a foundational principle of Speech Clause doctrine that adults may not be reduced "to reading only what is fit for children," (Butler v. Michigan, 1957 , p. 383) or, to put it more dramatically, the "level of discourse reaching a mailbox simply cannot be limited to that which would be suitable for a sandbox" (Bolger v. Youngs Drug Products Corp., 1983, p.74).

Minors also have rights under the Speech Clause, both to speak and to receive speech (Tinker v. Des Moines Ind. Schl. Dist., 1969; Ross, 1999). The rights of minors are not, in this instance as in many others, coextensive with those of adults. Under the legal concept of "variable obscenity," the state may place special burdens on speech deemed obscene for minors, even if it is not obscene for adults (Ginsberg $v$. New York, 1968). Contemporary legislation designed to limit minors' access to speech that is protected for adults is generally modeled after the Miller test, with additional words such as "appeals to the prurient interest of minors" (Ginsberg, p. 633, emphasis added). Variable obscenity statutes will generally survive constitutional scrutiny only if the speech remains available to adults, and if the statute allows parents to make the material available to their children if they choose to do so (Ginsberg $v$. New York, 1968; Reno v. ACLU, 1997; Sable Communications, Inc. v. FCC, 1989).

Obscenity doctrine has had a tortured history even when properly applied to depictions of sex as required by the express language of Miller, which states that the regulated work must depict or describe "sexual conduct" in a "patently offensive way" (p. 15). Ignoring the Court's holding that obscene speech is limited to certain speech involving sex, many advocates of limiting violent speech to protect children have pinned their hopes on the obscenity model. They seek to expand the concept of obscenity to encompass excessive or egregious media depictions of violence. Kevin Saunders (1996, 2003), the leading proponent of this approach, argues that both sexual materials and graphic violence were historically treated as "obscene," and that graphic violence should be merged into modern obscenity law to protect children. People frequently refer to extreme violence in 
real life-such as decapitations--as "obscene." In conversation, "obscene' is often just a synonym for repulsive, with no sexual overtones at all" (American Amusement Machine Ass'n v. Kendrick, 2000, p. 575).

This real-world usage does not apply in the world of legal analysis. The Supreme Court draws a clear line between obscene speech under the Miller test and speech involving even the most graphic violent imagery. Courts have rejected every claim that violent imagery should be incorporated into the definition of obscene speech as applied to children (American Amusement Machine Ass'n $v$. Kendrick, 2000; Bookfriends v. Taft, 2002; Eclipse Enterprises v. Gulotta, 1997; Video Software Dealers Ass'n v. Maleng, 2004).

For example, a federal court enjoined enforcement of a broad Ohio criminal statute that labeled as "obscene" the dissemination to minors of material "harmful to juveniles" in all forms of media. In addition to the displays or depictions of sexual activity or bodily elimination deemed obscene to minors, commonly reached by variable obscenity statutes, the Ohio law banned depictions of "extreme or bizarre violence," and representations "in lurid detail of the violent physical torture, dismemberment, destruction or death of a human being" (p. 936). Even more troubling, Ohio sought to ban glorification of criminal activity in a manner tending to corrupt juveniles. The court squarely rejected Ohio's argument that it merely codified the Roth obscenity test as modified for juveniles by Ginsberg and updated by Miller. The court relied on the Supreme Court's statement in Erznoznik $v$. City of Jacksonville (1975) that "an expression 'must be, in some significant way, erotic" in order for the state to limit distribution to juveniles (Bookfriends v. Taft, 2002, p. 941).

Similarly, in overturning a narrower Indianapolis statute limiting minors' access to arcade video games depicting graphic violence, Judge Richard Posner, writing for the United States Court of Appeals for the
Seventh Circuit, declined the City's invitation to "squeeze the provision on violence into a familiar legal pigeonhole, that of obscenity, which is normally concerned with sex. . . . Violence and obscenity are distinct categories of objectionable depiction" (American Amusement Machine Ass'n v. Kendrick, 2000 , p. 574). He distinguished the effort to ban violent speech as quasi-obscene when made available to minors from efforts to protect children from harm. The concerns animating the two approaches were quite different, he concluded. Obscene speech is not banned because it is harmful, but because it is offensive: "disgusting, embarrassing, degrading, disturbing, outrageous and insulting." But, Judge Posner noted, obscenity "is not believed to inflict temporal (as distinct from spiritual) harm" (American Amusement Machine Ass'n v. Kendrick, 2000, p. 575).

These decisions make clear that violent imagery cannot be shoehorned into obscene or otherwise unprotected speech that can be regulated based on its content.

\section{THE STATE'S BURDEN TO DEMONSTRATE THAT VIOLENT SPEECH HARMS CHILDREN}

This section examines the fate of other limitations on speech that were justified on the basis of preventing speech that is "harmful to minors" from reaching them. It then sets forth the standards that the government must meet in order to establish a compelling interest in regulating speech to protect children. Finally, it asks whether the government is likely to meet that burden based on the available evidence about the effect of violent speech on minors, and concludes that it will not.

\section{The Fate of the "Harmful to Minors" Argument in the Supreme Court}

The Supreme Court has expressly stated that the "salutary purpose of protecting 
children" does not insulate government action from constitutional scrutiny" (Interstate Circuit v. City of Dallas, 1968, p. 689). Over the last two decades, the Supreme Court has overturned most of the federal statutes it reviewed that were intended to shield children from speech that Congress regarded as indecent but not obscene (hereinafter, "controversial" speech) (Ross, 2000). The statutes the Supreme Court struck down were not narrowly tailored to protect the rights of adults as required to survive scrutiny under the Speech Clause. The laws struck down included federal efforts to shelter children from commercial telephone sex messages (Sable Communications, Inc. v. FCC, 1989); limit indecency on leased and public access cable television channels (Denver Area Educ. Telecom Consortium, Inc. v. FCC, 1996); and control transmissions from subscription adult cable channels so that they did not inadvertently reach children whose parents did not subscribe (United States $v$. Playboy Entertainment Group, Inc., 2000). The Supreme Court has also overturned or sent back to lower courts for further consideration several Congressional efforts to regulate indecent speech on the Internet (ACLU v. Reno, 2000; Ashcroft v. ACLU, 2002, 2004; Reno v. ACLU, 1997).

In addition to Ginsberg, discussed above, there are only two other cases in which the Supreme Court has upheld federal regulation of indecency designed to protect children. The first, decided more than 25 years ago, is widely regarded as the apex of the Court's expansion of the concept of indecency and the government's ability to regulate it in a specific form of media. In FCC $v$. Pacifica Foundation (1978), the Court upheld Federal Communications Commission sanctions imposed on a radio station for programming that used foul language during the afternoon. The Court distinguished radio from other forms of communication, keeping up a long tradition of court rulings discussing speech rights in the context of the form of communication at issue (such as print, radio, broadcast television, cable, Internet). Regulations governing when certain material may be broadcast on radio, known as "safe harbors," remain in effect today. But when the FCC overreaches by, for example, banning all indecent broadcasts, regardless of the time of day, lower courts have overturned the agency's regulations and decisions (Action for Children's Television v. FCC, 1991).

The only other instance in which the Supreme Court has upheld regulations of speech designed to protect minors involved a federal statute that required public libraries to install filtering software to block images constituting obscenity or child pornography on all computers, and to install software filtering all materials "harmful to minors" on all computers available to them, as a condition of receiving federal funding (Children's Internet Protection Act, 2000). Once again, Congress was concerned about exposing children to sexual, rather than violent, speech. The plurality opinion by Chief Justice Rehnquist (an opinion expressing the reasoning of the winning side but signed by less than half of the Justices) turned on the distinction between government regulation of private speech and the right of the government to define the limits of the programs it chooses to finance. The two concurring opinions by Justices Breyer and Kennedy (at least one of which was needed to make up a majority) emphasize that the material intercepted by the filters remained available to adult users on request (United States $v$. American Library Ass'n, 2003). In instances where children's access to violent speech is not underwritten by the government, this case does not provide a useful precedent for limiting children's access.

In all of these cases, regardless of the outcome, the Supreme Court, like most lower courts, has failed to evaluate whether the targeted speech actually harmed children. 
Thus, the courts have generally accepted the government's argument that protecting children from indecent or sexually explicit speech constitutes a compelling government interest that justifies regulations on speech. With few exceptions, the courts have rubberstamped the government's compelling interest argument and focused almost exclusively on whether the regulation was narrowly crafted to achieve the government's goal, as required under the Speech Clause (Ross, 2000). None of the cases discussed in this section involved violent imagery.

\section{Standards for Establishing That the Government Has a Compelling Interest in Regulating Violent Speech}

It is not sufficient for the government merely to assert an abstract or generalized interest in children's development to establish that it has a compelling interest in limiting speech (Ross, 2000). Turner Broadcasting System v. FCC (1994) articulates an exacting test: "[W]hen the [g]overnment defends a regulation on speech as a means to ... prevent anticipated harms, it must do more than simply 'posit the existence of the disease sought to be cured. . . . It must demonstrate that the recited harms are real, not merely conjectural, and that the regulation will in fact alleviate these harms in a direct and material way" (Turner Broadcasting System v. FCC, Kennedy opinion, p. 664). If Turner is taken seriously, as it should be, courts must carefully review the government's claim of a compelling interest in regulating controversial speech to protect the young. In order to meet its burden, the government must demonstrate that (i) children's social, moral, or emotional development is at stake; (ii) the speech is the direct cause of the risk; and (iii) restricting the speech will in fact reduce the risk of harm. Significantly, a court must determine whether the government has demonstrated and defined its compelling interest in regulating any given form of speech before it asks hether the regulation is narrowly tailored to achieve the government interest without imposing an undue burden on speech (Ross, 2000).

Applying this standard to the social science literature concerning the impact of sexual speech on children, I have previously concluded that "it is nearly impossible to find an iota of evidence that controversial speech about sex harms children" (Ross, 2000 , p. 504). Concededly, the case for regulating violent imagery might be stronger. Substantial social science research supports the allegation that violent speech may lead some children to violent actions or attitudes, but such evidence is not uncontroverted (Ross, 2000, p. 505; Ross, 2000, as cited in American Amusement Machine Ass'n v. Kendrick, 2000).

\section{Can the Government Establish That Violent Speech Harms Children?}

Some observers argue that it is not necessary for the government to provide "scientifically certain criteria" in support of regulations affecting speech, based on the language upholding variable obscenity standards (American Amusement Machine Ass'n v. Kendrick, 2000; Ginsberg v. New York, 1968, p. 643). But in Ginsberg, the Supreme Court treated the indecent speech at issue as obscene when provided to minors and therefore outside the protection of the Speech Clause. Consequently, the Court did not apply strict scrutiny to the statute before it, using instead the lower standard of rational basis. The Court held that it was "rational" for the state to conclude that the speech it sought to regulate was "harmful to children." More is demanded when the state seeks to regulate violent speech, however, because violent speech is protected speech. Therefore any efforts to regulate it, even those reaching only minors, are subject to 
strict scrutiny. Strict scrutiny always begins with an analysis of whether the government has a compelling interest in regulating the speech it seeks to limit.

Two important and legally relevant questions about whether limiting violent speech would reduce societal violence are (i) whether some identifiable "subset" of violent speech in particular media causes "antisocial behavior of a sort that the state has a compelling interest in eliminating or reducing," and (ii) how much "societal violence the regulation would curb" (Edwards \& Berman, 1995, pp. 1546, 1549). In 1995, Edwards and Berman concluded that despite all of the congressional hearings on television violence since the early 1950 s, and despite the extensive research that has examined the "violence hypothesis" that viewing televised violence causes aggression, "there is scant data on the magnitude of the effect of television violence" (p. 1549). A decade later, a federal court in Washington State concluded after expert testimony that "no causal connection between playing violent video games and real-life violence has been established" (Video Software Dealers Ass'n $v$. Maleng, 2004, p. 1188). A federal appeals court also expressly rejected Missouri's argument that violent video games harmed children. The court observed that while the state's interest in protecting the "psychological well-being of minors" sounded "compelling in the abstract," the government had not met its burden to "demonstrate that the recited harms are real, not merely conjectural, and that the regulation will in fact alleviate these harms in a direct and material way" (Interactive Digital Software Ass'n v. St. Louis Co., 2003, p. 958, quoting Turner Broad. Sys. Inc. v. FCC, 1994, p. 664). Although social scientists such as Bushman and Anderson (2001) argue that society should be concerned even if violent media make only $1 \%$ of the population more aggressive, such a small effect would be insufficient to overcome constitutional values protecting speech.

Edwards and Berman (1995) argue that even "acceptance of the violence hypothesis does not establish that television violence is harmful to children viewers" (p. 1552). They point out that antisocial behavior in itself does not establish pathology, and assert that a different research question must be posed to determine whether televised violence harms children in some manner that does not gain expression in aggressive behavior. The authors found "little direct support" in the social science and medical literature for the hypothesis that watching violent television threatens the health of young viewers (p. 1552).

A more recent review of the social science literature from a legal viewpoint echoed Edwards and Berman's (1995) conclusion that the studies establish neither causation nor harm. Heins $(2001,2004)$ argues that the studies oversimplify the effect of viewing controversial material and ignore the social cognition perspective. In other words, different viewers (at different ages) respond differently to different types of expression.

This chapter does not undertake a new review of the literature. The inquiry here is limited to pointing out the nature and specificity of the evidence necessary to establish a compelling interest in state regulation of media violence. The confusion between correlation and causation continues to infect the literature on the links between violent entertainment and subsequent aggression. The authors of a leading study concede that even longitudinal studies provide weak evidence of causation, and that the effects found are modest (Huesmann, Moise-Titus, Podolski, \& Eron, 2003).

As Judge Posner has explained, the state cannot rest its case on "what everyone knows" about the harm violence in media causes to children. Common sense, he observed, may be just another name for 
"prejudice." He rejected the government's argument that two social science studies supported a link between playing violent video games and aggressive behavior. "The studies," the court held, "do not find that video games have ever caused anyone to commit a violent act, as opposed to feeling aggressive, or have caused the average level of violence to increase anywhere." In light of the flood of violent material available to children, Judge Posner concluded that as a matter of common sense, the claim of harm from video games alone was "implausible, at best wildly speculative" (American Amusement Machine Ass'n v. Kendrick, 2000, pp. 578-579).

The impact of television violence has been the subject of more scientific inquiry than violence in other media. An impressive array of experts has proclaimed that television violence endangers our children and our society. In 2000 , six major public health organizations, including the Academy of Pediatrics, the American Psychological Association, and the American Medical Association, issued a joint statement on televised violence. They concluded the following:

Well over 1,000 studies-including reports from the Surgeon General's office, the National Institute of Mental Health, and numerous studies conducted by leading figures within our medical and public health organizations- . . p point overwhelmingly to a causal connection between media violence and aggressive behavior in some children. The conclusion of the public health community, based on over 30 years of research, is that viewing entertainment violence can lead to increases in aggressive attitudes, values and behavior, particularly in children. Its effects are measurable and long lasting. Moreover, prolonged viewing of media violence can lead to emotional desensitization toward violence in real life. (quoted in Broadcast Decency Enforcement Act, 2004, pp. 7-8)
The 2004 report on television violence from a committee of the United States Senate pointed to this statement as establishing a consensus among behavioral scientists (Broadcast Decency Enforcement Act, 2004, p. 8). But as Freedman (2002, p. 13) has pointed out, there are only about 200 studies, not "thousands"; Freedman argues that those 200 studies do not live up to their claims. The respected British medical journal, The Lancet, has taken a similar position, stating, "it is inaccurate to imply that the published work strongly indicates a causal link between virtual and actual violence" (Heins, 2004, p. 244). These challenges to the significance of the research linking media violence to aggression have in turn provoked ongoing controversy.

Environmental factors may be at least as important as exposure to violence in the media as a causal factor for aggressive behavior. The same Senate committee quoted above observed that the risks of exposure to television violence were "especially acute for residents of inner city neighborhoods. One witness testified that "[v]iolence is the No. 1 cause of death in the African-American community. . . . The environment is permeated with violence. It is unsafe for children to walk to and from school" (Broadcast Decency Enforcement Act, 2004, p. 17). Each day in the United States, eight children are killed by firearms, on average three of them African American and one a Latino (Children's Defense Fund, 2004). Many other children, not themselves the victims of violence, witness violence around them and experience the fear that accompanies it. Research confirms that children exposed to high levels of neighborhood violence are more prone to think and behave aggressively than children who live in safer neighborhoods (Guerra, Huesmann, \& Spindler, 2003).

Johnson and colleagues (Johnson, Cohen, Smailes, Kasen, \& Brook, 2002) considered the common hypothesis that some or all of 
the correlation between watching violent material on television and aggression later in life could reflect the initial preferences of aggressive young people who desire violent entertainment. They identified a "bi-directional" relationship between television violence and aggressive behavior. The authors concluded that growing up in an unsafe neighborhood, in poverty, and having parents who had not graduated from high school-all acknowledged as childhood risk factors-were significantly associated with heavy television viewing, which, in turn, was associated with subsequent aggressive behavior.

The standard of proof that allows reasonable people to be concerned about the impact of media violence is much lower than the causal link required before the state restricts protected speech. To provide legally convincing evidence that viewing media violence or playing violent video games actually harms children, studies would need to distinguish more carefully among factors such as the level of exposure to violent entertainment, and violence and poverty in the community, than they generally have done to date. According to Huesmann et al. (2003), most scholars who study aggression "agree that severe aggressive and violent behavior seldom occurs unless there is a convergence of multiple predisposing and precipitating factors such as neurophysiological abnormalities, poor child rearing, socioeconomic deprivation, poor peer relations, attitudes and beliefs supporting aggression, drug and alcohol abuse, frustration, provocation and other factors" (p. 201). This complexity suggests that it would be hard to establish more than a simple positive correlation between watching violence on television and long-term aggression. Studies other than those that examine the impact of media violence offer variables that should be integrated into ongoing research. One study suggests that children who are the direct victims of violence (including domestic violence) demonstrate the highest level of behavioral problems, followed by children who have personally witnessed violence, and then by those "who were exposed through other people's report" or news coverage (Purugganan, Stein, Silver, \& Benenson, 2003).

Any enterprising youngster can easily find violence in newspapers, television news, and on Internet news pages. Even parents who are careful about what their children are exposed to in the media may find that headlines about violent realities that will be covered in the next scheduled news report interrupt programming for children. These exposures may not be comfortable, and parents may go to great lengths to avoid them, but they are constitutionally protected.

News coverage routinely contains abundant and graphic violence, but violent speech in the news cannot be regulated in any way consistent with the First Amendment (Miami Herald $v$. Tornillo, 1974). Suicide bombings in the Middle East and elsewhere, decapitations of hostages, the torture of Iraqi prisoners of war in Abu Ghraib prison, ethnic slaughter in Africa, Scott Peterson's murder of his wife and the fetus she was carrying, as well as myriad local assaults, homicides, and incidents of child abuse, are all shown without a thought of legal censorship.

The contrast to countries that lack our strong legal protection for speech is striking. Venezuela, for example, recently adopted a law prohibiting scenes of violence and sex from being broadcast during the daylight hours, ostensibly in order to shield children from harm. Opponents of the law charge that its real purpose is to block news coverage of violent protests and government crackdowns on demonstrators (Forero, 2004).

Although the Federal Communications Commission (FCC) has occasionally denied that the newsworthiness of a broadcast would necessarily protect the program from federal regulation, scholars disagree (Ross, 2000). An effort to control newscasts such as 
the one in place in Venezuela is unimaginable and certainly would not be legal in the United States. Moreover, the sliding scale of protection for indecent speech in the United States, from complete protection for news, to lesser protection for cable television, with broadcast television and radio subjected to higher levels of FCC regulation (Ross, 2000), suggests that it would be difficult to devise regulations addressing the problem of violent speech that would reach all depictions of violence regardless of their source. This broader context makes it much harder for the government to demonstrate that any proposed regulation of violent speech applied to any single method of communication would directly and effectively reduce "harm to children."

When freedom of speech is implicated, the Constitution requires that legislatures proceed cautiously and that courts exercise vigilant oversight. Scientific studies purporting to demonstrate the state's compelling interest in regulating violent speech to protect children must be carefully crafted to identify the precise harm caused by the speech, and to show that restrictions on speech would directly and materially alleviate the harm. The studies to date do not appear to have met that standard.

\section{DEFINING VIOLENT SPEECH}

The intertwined problems of how to define violent speech and who would define it pose yet another obstacle to regulation. One reason that the multitude of studies linking violent entertainment to aggression fail to identify a precise harm is that many or most of the studies fail to define what they count as media violence. The studies that do offer definitions do not use the same definition. As a result, even if the findings regarding causation were more compelling, the studies would not identify a precise harm (such as a heightened level of aggression or insecurity) or be able to show how restrictions on speech would directly alleviate the harm.

The problem of definition is central to the dilemma facing lawmakers who wish to regulate violent speech. Laws carrying criminal penalties must be crafted precisely in order to provide notice to people who might unwittingly violate them, such as television producers and broadcasters, or video game manufacturers. The failure to provide such notice is a fatal flaw in a criminal statute affecting speech (Reno v. ACLU, 1997). Equally important, in First Amendment parlance, it leads to "chill," a process in which speakers censor their own protected speech out of fear of prosecution.

The Broadcast Decency Enforcement Act of 2004 was one of a handful of congressional efforts to address media violence. The portion of the proposed legislation devoted to violent speech was adopted in the Senate, but not in the House of Representatives, and the legislation languished at the end of the congressional term (Broadcast Decency Enforcement Act, 2004; Steinberg, 2004). The Senate bill envisioned channeling violent programming to "safe harbor" hours when children were not "reasonably likely to comprise a substantial portion of the audience" (p. 21), but only if further FCC study confirmed the legislators' suspicion that the current industry-administered rating system and blocking technology, the violence- or V-chip, did not sufficiently protect children. Although the bill has not become law, the proposal is worth examining because it exemplifies the difficulties inherent in attempts to regulate violent speech.

The proposed legislation instructed the FCC to define the term "violent video programming" within 9 months as a prerequisite to further study and, if justified, to ultimate regulation (Broadcast Decency Enforcement Act, 2004, $\$ 715$ (b) (3)). The Senate committee report appreciated that defining the speech it intended to reach was not an easy 
task: "While it may be difficult to craft a definition of violent video programming, that is not overbroad, that is not vague, and that is consistent with the research of harm caused to children, these are exactly the tasks that the FCC was created to perform" (Broadcast Decency Enforcement Act, 2004, p. 19). The committee noted that state efforts to restrict the display to minors for sale or rental of any material containing "excess violence," have been overturned where the state defined the term inadequately (Davis-Kidd Booksellers, Inc. v. McWherter, 1993). The committee nonetheless concluded that although the "case demonstrates the difficulty of defining violent programming, it does not stand for the proposition that such term is incapable of being defined" (Broadcast Decency Enforcement Act, 2004, p. 20).

This flies in the face of the FCC's conclusion in 1972 that it could not prohibit broadcast violence because the subject matter would prove impossible to define. The Commission asked how it would treat the children's classic Peter Pan, in which the crocodile bites off the captain's hand, and ultimately eats him (Wise, 1996, pp. 34-35). The passage of time has not made violence any easier to define. As one congressman wondered in 1999, does violence mean "a movie like 'Home Alone' . . . a movie like 'Ben Hur' . . . [or] a movie like '[Saving] Private Ryan?'” (Mitchell \& Bruni, 1999).

Five years later, numerous $\mathrm{ABC}$ affiliate stations refused to broadcast the unedited Academy Award-winning Saving Private Ryan, because they feared being sanctioned under the FCC's broadening expansion of standards governing indecency. The soldiers apparently swore like sailors. Station owners requested, but did not receive, an advance waiver from the FCC, which told them to use "their own good faith judgment" (de Moraes, 2004, p. C-7).

In this classic example of chilled speech, the station owners were intimidated by the
FCC's perceived crackdown after notorious incidents in which rock star Janet Jackson bared her breast during the Super Bowl, and singer Bono used the f-word when being honored at a ceremony broadcast on network television. ABC inserted 11 parental advisories during Saving Private Ryan, but that did not reassure its mutinous affiliates. ABC's affiliates emphasized that their concern about the film lay in the FCC's reaction to profanity, not the violent matter contained in prolonged and realistic battle scenes, since the FCC does not regulate violence. The Parents Television Council, a watchdog group, agreed with $\mathrm{ABC}$ that in context, "the content is not meant to shock, nor is it gratuitous" (de Moraes, 2004, p. C-7).

Context is hard to capture in legislation, and perceptions may differ. Even if legislators could agree on a specific definition of violent speech, presumably some sort of protection would need to be accorded to speech containing violent images that (to paraphrase the Miller obscenity standard), "taken as a whole," demonstrate serious literary, artistic, political, or scientific value. Under First Amendment doctrine, even when the government has established a compelling interest in regulating speech, the regulation must be narrowly crafted so that it reaches no more speech than is absolutely necessary. While this chapter does not detail how a regulation designed to limit children's exposure to violent speech might be narrowly tailored in order to pass muster, any proposed government regulation would need to define speech in a way that assures that "legitimate speech is not chilled or punished" (Ashcroft $v$. ACLU, 2004, p. 2791).

Shakespeare's Romeo \& Juliet, for example, contains sex and violence. In fact, the violence is more graphic than the sex, resulting in the suicide of both teenagers. Hunters shoot Bambi's mother early in the classic children's film, and Babar's mother is similarly disposed of in the first volume of the book series. 
Consideration of whether violence is "gratuitous" in context also requires differentiation among minors of varying ages and levels of maturity. Legislation designed to restrict the access of children to violent speech to date has lacked such subtlety.

As noted above, children have First Amendment rights. Judge Posner, presuming that the statute before him did not intend to limit the access of young people to such classic works of literature as The Odyssey, War and Peace, or Edgar Allen Poe's writing, explained,

[v]iolence has always been and remains a central interest of humankind and a recurrent, even obsessive theme of culture high and low. It engages the interest of children from an early age, as anyone familiar with the classic tales collected by Grimm, Andersen, and Perrault is aware. To shield children right up to the age of 18 from exposure to violent descriptions and images would not only be quixotic, but deforming: it would leave them unequipped to cope with the world as we know it. (American Amusement Machine Ass'n v. Kendrick, 2000, p. 577)

Judge Posner pointed out that since young people may vote at age 18 , "it is obvious that they must be allowed to form their political views on the basis of uncensored speech before they turn eighteen, so that their minds are not a blank when they first exercise the franchise" (American Amusement Machine Ass'n v. Kendrick, 2000 , p. 577). Likewise, since 18 -year-olds may also enlist in the armed forces without parental permission, it might prove useful for them to have already seen Saving Private Ryan, or read War and Peace, so that they would understand the risks of military service before signing up.

Whose values will we, as a society, trust to draw the lines between permissible and impermissible violence in the context of art?
There is no objective, ascertainable standard with which to measure value. As Justice Scalia has stated with reference to the third prong of the Miller test for obscenity, asking jurors to make reasonable judgments about such matters is "quite impossible . . . there being many accomplished people who have found literature in Dada, and art in the replications of a soup can." Such decisions, he observed, if not always impossible, are "at least impossible in the cases that matter" (Pope v. Illinois, 1987, pp. 504-505 [Scalia, J., concurring]).

\section{PARENTAL RIGHTS AND RESPONSIBILITIES}

Reasonable parents differ. When the state seeks to regulate speech that reaches children, it often argues that in trying to protect children directly, it also seeks to empower parents by helping them to enforce the rules they impose on their children. But this argument is misleading because parents do not all exercise discretion over their children in identical ways. Parental values and judgments may vary considerably, and are affected by parents' knowledge of their individual children.

For heuristic purposes, three categories of families reflect the complex relationship among government actors, mainstream mores, and each family's values. First, in an "idealized normative family," the parents share the values of government actors and also share an identical understanding of how to best transmit those values to the next generation. Second, in the "imperfect normative family," the parents share the general preferences of the government actors but fail, through lack of information, fatigue, or overextension, to protect their children from speech they view as potentially harmful. Third, the "nonconformist family" does not share the values and choices of the dominant 
culture as interpreted by lawmakers. The nonconformist family comes in countless varieties, at both ends of the spectrum of tolerance for controversial speech in all of its forms, including violent speech (Ross, 2000).

When the government seeks to make any kind of controversial speech more difficult for minors to obtain in the name of helping parents, it tacitly discounts the ability of parents in all categories of families to raise their children as they see fit. If $90 \%$ of parents do not use the V-chip to limit their children's television viewing, only a fraction of parents know the meaning of all of the content-rating categories, and the majority of children have television sets in their own bedrooms (Broadcast Decency Enforcement Act, 2004), these facts reflect parental choices.

Another message, based on the presumed prevalence of imperfect normative families, is that responsible parenting is virtually impossible even for the most well-intentioned parents. This line of argument suggests that the transmission of values ought to be delegated, at least in part, to the state even outside of school hours. But government regulation based on this premise would trample minority views.

When the state divides speech that reaches children into favored and disfavored categories, it sends a message that nonconformist parenting is irresponsible at best. If the parenting is irresponsible enough to rise to the level of abuse or neglect, laws are already in place allowing government intervention. When government favors one set of values over others, the government risks marginalizing at least some types of nonconformist families. The government's endorsement of one position sends a message to neighbors and schoolmates that the nonconformist family is a bad family. Parents, however, have a constitutional right, recognized by the Supreme Court, to make decisions affecting how their children are raised (Troxel $v$. Granville, 2000), as long as they do not cross the line to neglect or abuse. The government may regulate children's access to substances such as tobacco and alcohol, which pose demonstrated risks to health and do not involve speech or any other protected right, but may not regulate children's exposure to ideas made available in their homes.

The argument that the state may not regulate the violent speech available to children does not in any way constrain parental efforts to limit the violent imagery to which their own children are exposed. On the contrary, it may strengthen the argument that parents should set some limits on what their children see, limits that convey their own judgments about the specific material and the specific child.

Judge Harry T. Edwards of the Court of Appeals for the D.C. Circuit has authored several thoughtful separate opinions in cases that raise issues about the government's ability to limit speech in order to protect children (Action for Children's Television v. FCC, 1995; Alliance for Community Media v. FCC, 1995). Edwards \& Berman (1995) concluded that television violence is protected speech not subject to government regulation. Judge Edwards has eloquently captured the distinction between decisions made by the government and those made by parents and the limits imposed on government regulation by the Constitution:

As a constitutional scholar, long-time law teacher, and fervent advocate of the First Amendment, I am not surprised by the conclusions I have reached. But, as a father and step-father of four children, the husband of a trial judge in Washington, D.C. who works with the perpetrators and victims of juvenile violence every day, and an AfroAmerican who has watched the younger generation of his race slaughtered by the blight of violence and drugs in the innercities of America, I am disappointed that more regulation is not possible. . . It is no answer for a parent like me to know that 
I can (and will) regulate the behavior of my children, because I know that there are so many other children in society who do not have the benefit of the nurturing home that I provide. If I could play God, I would give content to the notion of "gratuitous" violence, and then I would ban it from the earth. I am not God, however, so I do not know how to reach gratuitous violence without doing violence to our Constitution (Edwards \& Berman, 1995, p. 1566)

Certainly individual parents will make different choices about what kind of speech threatens to harm their children, and how much help they want or need in making or enforcing their child-rearing decisions. If the state makes distribution of violent material to minors a crime, it does violence to parental discretion as well as to the Constitution. When the governor of Illinois proposed legislation in 2004 to bar the distribution to minors of video games containing violence, an informal sampling of parental opinion revealed that some parents did not welcome the help. As one mother of three teenagers put it, "I don't feel that the state Legislature can do a good job of dictating to parents on how to raise our children. [Under the proposed legislation] we're putting our responsibility as a parent now onto a retailer. That is not going to work" (National Public Radio, 2004).

Sensitive ratings and filters can assist parents who do want help in making judgments about content. To the extent that producers and retailers voluntarily adopt such systems and parents can choose whether or not to use them, they pose no constitutional problem (Delgado $v$. American MultiCinema, 1999). The Constitution does not appear to pose any obstacles to government actions designed to facilitate the technical availability of filtering systems, such as imposing technical regulations that insure the compatibility of filtering mechanisms with transmission, or requiring manufacturers to install V-chips in television sets as Congress did in the mid-1990s (Telecommunications Act of 1996). In addition, while Congress may not require that parents use filters on televisions or computers, it may encourage the use of filtering mechanisms. Voluntary parental use of filters or lock devices helps those parents who wish to restrict their children's access to violent speech, and who seek help in doing so, without either imposing the government's views on parents who have different opinions or subjecting protected speech to penalties (Ashcroft $v$. ACLU, 2004).

Current flaws in the ratings systems for television and video games fuel the momentum for governmental action. According to recent Senate findings, nearly $80 \%$ of violent television programming remains unrated for violence, rendering $\mathrm{V}$-chips programmed for violence useless. Age-based ratings for both television and video games may also fail to identify violent content (Broadcast Decency Enforcement Act, 2004, \$ 202; National Public Radio, 2004). Similarly, filters for computers may be both under-inclusive (failing to block all objectionable speech) and over-inclusive (blocking valuable and harmless speech).

In order to accomplish their intended goal, ratings and filters should provide parents with as much information as possible so they can understand the basis for industry classifications. Development of a variety of rating systems attuned to different sensibilities offers a rich arena for child advocates concerned about violent speech.

Families might also benefit from information regarding the scientific research in this area, written in nonscientific and accessible language, that can help parents form their own opinions. One recent study found that "the violent films and TV programs that probably have the most deleterious effects on children are not always the ones that adults and critics believe are the most violent." The 
authors concluded that children were most likely to be influenced by depictions of violence when they identified with the perpetrator, perceived the story as "telling about life like it is," and saw the perpetrator as being "rewarded for the violence." Parents, they argued, "need to be educated about these facts" (Huesmann et al., 2003, p. 218). If ratings reflected more nuanced thinking and contained more information, parents who wish to shelter their children from violent material as well as those who wish to share and discuss some types of violent material with their children would both be empowered. Media literacy education that teaches children how to think critically about what they see and hear offers another constructive and constitutional response to societal and parental concerns (Heins, 2004).

\section{CONCLUSION}

As a society, we cannot begin to approach the problem of violent speech in a thoughtful way until we can define the speech that is too violent, and do so in a way that takes into account its context, including its social value and the listener's age. Even if the proponents of regulation could solve the dilemma of how to define violent speech with precision, which seems unlikely, any effort to regulate violent speech must meet the demands of the First Amendment. Thus, the state must justify any proposed regulation of violent speech by establishing that it causes a specific harm to minors and that regulation will decrease that harm. The current evidence supports neither proposition. If the state could meet all of these demands, it would also have to succeed in crafting a narrowly tailored regulation that inhibits no more speech than necessary to achieve the precisely defined goal. The inherent difficulty is that this final task underscores, and is entwined with, the seemingly intractable initial problem of how to define violent speech.

While this chapter does not demonstrate that no constitutionally sound approach could ever exist in response to popular concerns about violent speech, it does conclude that difficult obstacles confront any government effort to shelter children from violence in the media. Violent speech is protected under the First Amendment. Ever since video games have been recognized as speech, no city or state has succeeded in crafting a regulation of violent speech in any medium that has survived judicial review. The prospects for any regulation that will comport with the Speech Clause seem dim at best. And this is just as well. The rights of parents to exercise discretion in raising their children, the rights of older minors to be exposed to speech of all kinds, as well as the rights of speakers are at stake. The best public response to violent speech remains information and education, not censorship.

\section{REFERENCES}

ACLU v. Ashcroft, 322 F. 3d 240 (3rd Cir. 2003), aff'd and remanded sub nom Ashcroft v. ACLU, 124 S. Ct. 2783 (2004).

ACLU v. Reno, 217 F. 3d 162 (3rd Cir, 2000), vacated and remanded sub nom Ashcroft v. ACLU, 535 U.S. 564 (2002).

Action for Children's Television v. FCC, 932 F.2d 1504 (D.C. Cir. 1991).

Action for Children's Television v. FCC, 59 F.3d 1249 (D.C. Cir. 1995), cert.

denied, 516 U.S. 1072 (1996). 
Alliance for Community Media v. FCC, 56 F. 3d 105 (D.C. 1995), rev'd sub nom Turner Broadcasting System v. FCC, 512 U.S. 622 (1994).

American Amusement Machine Ass'n v. Kendrick, 115 F. Supp.2d 943 (S.D. Indiana, 2000) rev'd, 244 F.3d 572 (7th Cir. 2001) (Posner, J.), cert. denied, 534 U.S. 994 (2001).

American Best Family Showplace Corp. v. City of New York, 536 F. Supp. 170 (E.D.N.Y. 1982).

Ashcroft v. ACLU, 535 U.S. 564 (2002).

Ashcroft v. ACLU, 1542 U.S. 656 (2004).

Bok, S. (1997). Censorship and media violence. Michigan Law Review, 95, 2160-2161.

Bolger v. Youngs Drug Products Corp., 463 U.S. 60, 74 (1983).

Bookfriends v. Taft, 223 F. Supp.2d 932 (S.D. Ohio, 2002).

Brandenburg v. Ohio, 395 U.S. 444, 447-48 (1969).

Broadcast Decency Enforcement Act (2004). 108th Cong. 2d Sess. S. 2056 (April 5, 2004). Report of the Committee on Commerce, Science, and Transportation on S. 2056, Report 108-253.

Bushman, B. J., \& Anderson, C. A. (2001). Media violence and the American public: Scientific facts versus media misinformation. American Psychologist, $56,477-489$.

Butler v. Michigan, 352 U.S. 380, 383 (1957).

Chaplinsky v. New Hampshire, 315 U.S. 568 (1942).

Children's Defense Fund. (2004). Each day in America, August 2004. Retrieved December 8, 2004, from www.children'sdefensefund.org/data/eachday.asp

Children's Internet Protection Act. (2000). P. L. No. 106-554, tit. XVII, 114 Stat, 2763A-335.

Davis-Kidd Booksellers, Inc. v. McWherter, 866 S.W. 2d (Tenn. 1993).

Delgado v. American Multi-Cinema, 85 Cal Rptr. 2d 838 (1999).

de Moraes, L. (2004, November 11) "Saving Private Ryan": A new casualty of the indecency war. The Washington Post, C-1, C-7.

Denver Area Educ. Telecom Consortium, Inc. v. FCC, 518 U.S. 727 (1996).

Dienes, C. T., Levine, L., \& Lind, R. C. (1999). Newsgathering and the law (2nd ed.). Charlottesville, VA: Lexis Law.

Eclipse Enterprises v. Gulotta, 134 F.3d 63 (2d Cir. 1997).

Edwards, H. T, \& Berman, M. N. (1995). Regulating violence on television. Northwestern University Law Review, 89, 1487-1566.

Erznoznik v. City of Jacksonville, 422 U.S. 205 (1975).

FCC v. Pacifica Fdn., 438 U.S. 726 (1978).

Forero, J. (2004, December 9). Venezuela chief signs press law some see as aimed at his critics. New York Times, p. A-5.

Freedman, J. L. (2002). Media violence and its effect on aggression: Assessing the scientific evidence. Toronto: University of Toronto Press.

Ginsberg v. New York, 390 U.S. 629 (1968).

Guerra, N., Huesmann, L. R., \& Spindler, A. (2003). Community violence exposure, social cognition, and aggression among urban elementary school children. Child Development, 74(5), 1561-1576.

Heins, M. (2001). Not in front of the children: "Indecency," censorship, and the innocence of youth. New York: Hill \& Wang.

Heins, M. (2004). On protecting children-from censorship: A reply to Amitai Etzioni. Chicago-Kent Law Review, 79, 229-255. 
Hess v. Indiana, 414 U.S. 105 (1973).

Huesmann, L. R., Moise-Titus, J., Podolski, C., \& Eron, L. D. (2003). Longitudinal relations between children's exposure to TV violence and their aggressive and violent behavior in young adulthood: 1977-1992, Development Psychology, 39, 201-221.

Interactive Digital Software Ass'n v. St. Louis County, 200 F. Supp.2d 1126 (E.D. Mo. 2002), rev'd 329 F. 3d 954 (8th Cir. 2003).

Interstate Circuit v. City of Dallas, 390 U.S. 676 (1968).

Jacobellis v. Ohio, 378 U.S. 184 (1964) (Stewart, J., concurring).

Johnson, J. G., Cohen, P., Smailes, E. M., Kasen, S., \& Brook, J. S. (2002). Television viewing and aggressive behavior during adolescence and adulthood. Science, 295, 2468-2471.

Kalven, H., Jr. (1989). A worthy tradition: Freedom of speech in America (J. Kalven, Ed.). New York: Harper \& Row.

Krattenmaker, T. G., \& Powe, L. A., Jr. (1995). Converging first amendment principles for converging communications media. Yale Law Journal, 104, 1719.

Li, W. (2003). Unbaking the adolescent cake: The constitutional implications of imposing tort liability on publishers of violent video games. Arizona Law Review, 45, 467-483.

Miami Herald v. Tornillo, 418 U.S. 241 (1974).

Miller v. California, 413 U.S. 15 (1973).

Mitchell, A., \& Bruni, F. (1999, June 17). House undertakes days-long battle on youth violence. New York Times, A-1, A-26.

Montz, V. T. (2002). Recent incitement claims against publishers and filmmakers: Restraints on first amendment rights or proper limits on violent speech? Virginia Sports and Entertainment Law Journal, 1, 171-210.

National Public Radio. (2004, December 16). Analysis: Illinois Governor Rod Blagojevich wants to make selling or renting violent or sexual video games to minors a crime [radio broadcast]. Chicago: Author.

New York Times v. Sullivan, 376 N.Y. 254 (1964).

Paris Adult Theater I v. Slaton, 413 U.S. 49, 70-114 (Douglas, J., dissenting; Brennan, J., dissenting) (1973).

Phillips, N. (2004). Interactive Digital Software Ass'n v. St. Louis County: The first amendment and minors' access to violent video games. Berkeley Technology Law Journal, 19, 585-592.

Police Dep't of the City of Chicago v. Mosley, 408 U.S. 92 (1972).

Pope v. Illinois, 481 U.S. 497 (Scalia, J., concurring) (1987).

Purugganan, O. H., Stein, R. E., Silver, E. J., \& Benenson, B. S. (2003). Exposure to violence and psychosocial adjustment among urban school-aged children, J. Dev. Behav. Pediatrics, 24, 424-30.

R.A.V. v. City of St. Paul, 505 U.S. 377, 382 (1992).

Reno v. ACLU, 521 U.S. 844 (1997).

Ross, C. J. (1997). Comments, Association of American Law Schools, section on Mass Communications Law, 1997 Annual Conference Panel: Sex, violence, children, and the media: Legal, historical, and empirical perspectives. 5 CommLaw Conspectus 41, 349-351.

Ross, C. J. (1999). An emerging right for mature minors to receive information. University of Pennsylvania Journal of Constitutional Law, 2, 223-275.

Ross, C. J. (2000). Anything goes: Examining the state's interest in protecting children from controversial speech. Vanderbilt Law Review, 53, 427-524. 
Roth v. United States, 354 U.S. 476 (1957).

Sable Communications, Inc. v. FCC, 492 U.S. 115 (1989).

Salamon, J. (2005, Jan. 7). The rating says PG, but is that guidance enough? New York Times, E-1.

Saunders, K. W. (2003) Saving our children from the first amendment. New York: New York University Press.

Saunders, K. W. (1996). Violence as obscenity: Limiting the media's first amendment protection. Durham, NC, and London: Duke University Press.

Steinberg, J. (2004, June 7). Move to stiffen decency rules is losing steam in Washington. New York Times, C-1.

Telecommunications Act of 1996 (1996). P. L. No. 104-104, 110 Stat. 56.

Texas v. Johnson, 491 U.S. 397 (1989).

Tinker v. Des Moines Independent Community School Dist., 393 U.S. 503 (1969).

Troxel v. Granville, 530 U.S. 57 (2000).

Turner Broadcasting System v. FCC, 512 U.S. 622 (1994).

United States v. American Library Ass'n, 539 U.S. 194 (2003).

United States Constitution, Amendment 1.

United States v. Playboy Entertainment Group, Inc., 529 U.S. 803, 812 (2000).

Video Software Dealers Ass'n v. Maleng, 325 F. Supp.2d 1180 (W.D. Washington, 2004).

Winters v. New York, 333 U.S. 506 (1948).

Wise, E. (1996). A historical perspective on the protection of children from broadcast indecency. Villanova Sports \& Entertainment Law Journal, 3, 15-43. 